\title{
Analisis Eksistensi Benda Cagar Budaya dalam Tata Ruang Kota Guna Mendukung Pelestariannya di Kota Surakarta
}

\author{
Existence Analysist of Cultural Heritage Objects in Surakarta City \\ Planning for Supporting its Preservation
}

\author{
Nindya Ayu Wardani ${ }^{1}$, Baba Barus ${ }^{2}$ dan Siti Nurisyah ${ }^{3}$
}

Diterima: 18 November 2018 Disetujui: 6 September 2019

\begin{abstract}
Abstrak: Kota Surakarta merupakan Pusat Kegiatan Nasional yang memiliki 171 Benda Cagar Budaya yang perlu dilestarikan. Tekanan pembangunan memberikan tekanan bagi eksistensi Benda Cagar Budaya. Kemampuan Benda Cagar Budaya dalam mempertahankan eksistensinya, dapat dilihat berdasarkan tingkat risiko. Penelitian ini bertujuan untuk mengidentifikasi dan mengkategorisasi Benda Cagar Budaya di Kota Surakarta untuk kemudian dilakukan analisis risiko kehilangan Benda Cagar Budaya. Penetapan risiko Benda Cagar Budaya didasarkan pada interaksi antara kerentanan dan bahaya. Penelitian ini dilakukan melalui teknik klasifikasi visual pada citra satelit resolusi tinggi, Weighted Overlay, Analisis Overlay dan Analisis Deskriptif. Benda Cagar Budaya Kota Surakarta sebagian besar memiliki usia 100-200 Tahun yang didominasi oleh langgam arsitektur tradisional jawa. BCB tidak sepenuhnya berada dalam kondisi baik, sebanyak 35 unit mengalami kerusakan sebagian, 9 unit mengalami kerusakan total, dan 5 unit telah mengalami modernisasi. Sebanyak 33 Benda Cagar Budaya dengan luas 886.556 meter2 (46,09\%) berada pada tingkat risiko tinggi. Hasil penelitian ini diharapkan mampu menjadi bahan pertimbangan dalam penyusunan rencana penataan ruang dan pembangunan sebagai upaya perlindungan eksistensi benda cagar budaya.
\end{abstract}

Kata kunci: $B C B$, weighted overlay, risiko. Kerentanan, bahaya

\begin{abstract}
The City of Surakarta, one of National Activity Center and also known as Eco Cultural City, has 171 cultural heritage objects have to be preserved. City development that leads to modernization, physically, is a threat to the existence of those cultural heritage objects.To minimize lost of these valuable objects, risk management method, which is based on the interaction between their vulnerability and hazard, could be carried out. This study was aimed to identify and categorize cultural heritage objects at the city, to analyze the risk of losing of cultural heritage objects, and to recommend future city spatial planning in relation to cultural heritage objects. This research was conducted through visual classification techniques on high resolution satellite imagery, Weighted Overlay, Overlay Analysis and Descriptive Analysis. Surakarta City's cultural heritage objects mostly have 100-200 years old which is dominated by traditional Javanese architectural styles. Cultural heritage objects are not fully in good condition, as many as 35 units were partially damaged, 9 units suffered total damage, and 5 units have experienced modernization. A total of 33 cultural heritage objects covered an area of 886,556 square meters (46.09\%) are at a high risk of losing their existence. To protect the existence of cultural heritage, the result research should to considered of the city developtment program.
\end{abstract}

Keywords: cultural heritage, weighted overlay, risk, vulneranility, hazard

\footnotetext{
${ }^{1}$ Pascasarjana Institut Pertanian Bogor

2 Departemen Ilmu Tanah dan Sumber Daya Lahan, Fakultas Pertanian, Institut Pertanian Bogor

${ }^{3}$ Pusat Pengkajian Perencanaan dan Pengembangan Wilayah, LPPM, Institut Pertanian Bogor
} 


\section{PENDAHULUAN}

Benda Cagar Budaya (BCB) merupakan warisan masa lampau yang memiliki sifat kebendaan dan perlu dilestarikan keberadaannya karena memiliki nilai penting bagi sejarah, ilmu pengetahuan, pendidikan, agama, dan/ atau kebudayaan melalui proses penetapan (Undang Undang No. 11 Tahun 2010 tentang Cagar Budaya). BCB memiliki sifat unik, langka, mudah rapuh, tidak dapat diperbaharui, tidak bisa digantikan oleh teknologi dan bahan yang sama, serta penting karena merupakan bukti aktivitas manusia di masa lampau (Wibowo 2012). BCB juga mampu memberikan gambaran sejarah dan budaya di suatu tempat (Mansor et al. 2013). Karena itu, BCB perlu untuk dipertahankan atau dilestarikan eksistensi dan nilainya dengan cara melindungi, mengembangkan, dan memanfaatkannya dengan tepat. Pelestarian cagar budaya bukan hanya sekedar mempertahankan keberadaan fisik, melainkan juga memberikan identitas perkotaan secara berkelanjutan kepada generasi mendatang (Shafaghat et al. 2017).

Kota Surakarta, dahulu merupakan pusat pemerintahan dan perkembangan budaya Jawa. Kota ini dibangun pada tahun 1745 yang diawali dengan pembangunan Kraton Kasunanan Surakarta. Pada masa penjajahan Belanda, kota ini ditetapkan sebagai Vorstenlanden atau "wilayah kerajaan" yaitu di bawah otoritas empat monarki asli Jawa pecahan Dinasti Mataram Islam. Sejarah panjang kota ini meninggalkan jejak berupa BCB yang tersebar di seluruh wilayah kota. Kota Surakarta merupakan kota yang tumbuh dengan akar budaya yang kuat didukung oleh visi pembangunannya sebagai Eco Cultural City. Keberadaan 171 buah BCB yang diposisikan sebagai potensi dasar, pendekatan pemikiran dan orientasi pembangunan kota yang dilaksanakan secara seimbang dan berkelanjutan (Runa et al. 2011).

Keberadaan BCB idealnya menjadi pertimbangan dalam menyusun arah perkembangan kota. Akan tetapi, pembangunan kota-kota cenderung tidak memperhatikan eksistensi $\mathrm{BCB}$ bahkan mengarah pada meningkatnya kerusakan dan kehilangannya. Menurut ICOMOS (2015) kehilangan BCB sama halnya dengan kehilangan identitas dan nilai kesejarahan/artifak kota. Berdasarkan nilai-nilai penting yang dimiliki BCB ini, maka perlu dilakukan tindakan untuk mengantisipasi semakin berkurangnya $\mathrm{BCB}$ dalam wilayah perkotaan.

Sama halnya dengan sebagian besar kota di negara berkembang, di Kota Surakarta, manajemen risiko belum dijadikan pertimbangan dalam penyusunan kebijakan pelestarian BCB. Risiko kehilangan BCB dapat diprediksi melalui interaksi antara bahaya dan kerentanannya. Penilaian Risiko menurut Tarraguel (2011) juga diduga mampu menjadi dasar pertimbangan dalam mempersiapkan kebijakan yang lebih efektif dalam upaya pelestarian BCB. Penelitian ini bertujuan untuk (1) Mengidentifikasi dan mengkategorisasi BCB di Kota Surakarta, (2) Mengukur dan memetakan tingkat risiko kehilangan BCB Kota Surakarta, dan (3) Menyusun rekomendasi untuk penataan ruang wilayah Kota Surakarta.

\section{METODE PENELITIAN}

\section{Lokasi dan Waktu Penelitian}

Penelitian ini dilaksanakan di Kota Surakarta, yaitu kota yang berencana mencanangkan diri sebagai World Heritage City. Kota Surakarta merupakan salah satu kota administradi di Provinsi Jawa Tengah, dengan luas wilayah 44,04 Km2 dan terdiri dari 5 Kecamatan, 51 Kelurahan. Penelitian ini dilaksanakan pada bulan Juni hingga September 2018. Gambaran Lokasi Penelitian dapat dilihat pada Gambar 1. 


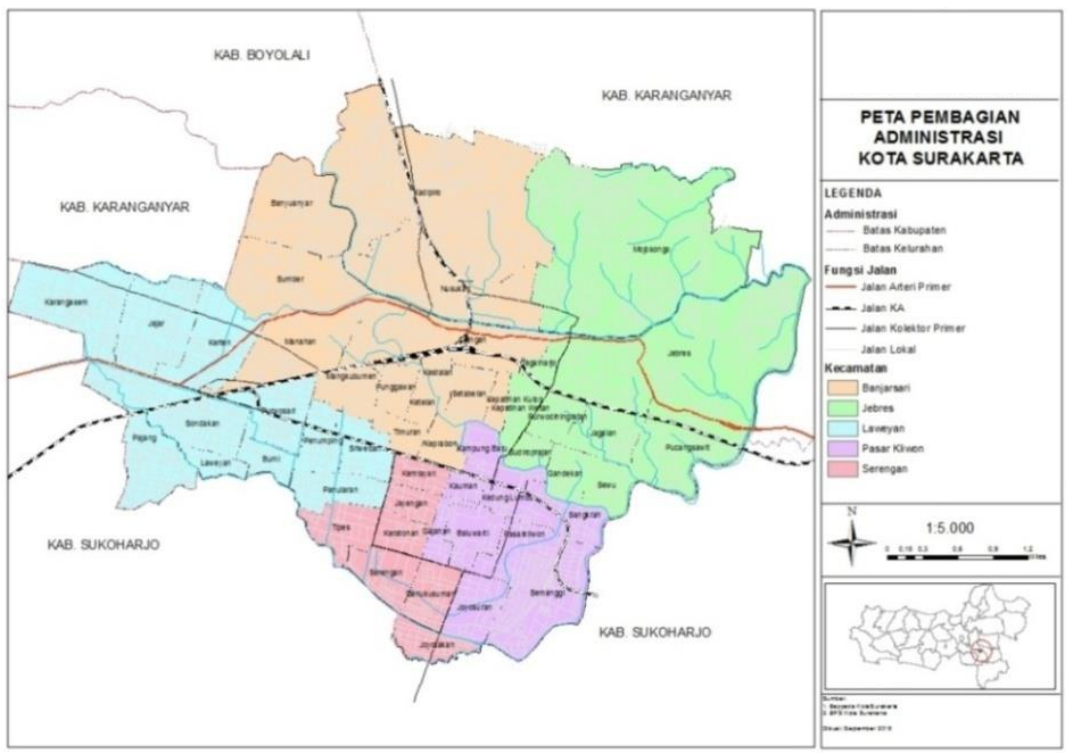

Gambar 1. Lokasi penelitian

\section{Jenis dan Sumber Data}

Data yang digunakan dalam penelitian ini terdiri dari 2 (dua) jenis data berdasarkan sumber perolehan datanya yaitu Data Primer dan Data Sekunder. Data primer merupakan sumber data yang langsung diperoleh kepada pengumpul data/peneliti. Data primer diperoleh secara langsung dari responden melalui wawancara, observasi maupun pengamatan langsung di lapangan. Jenis data lain yang digunakan dalam penelitian ini adalah Data Sekunder yang merupakan data data yang berasal dari sumber literatur, artikel dan berbagai sumber lainnya yang berhubungan dengan penelitian (Sugiyono 2010). Jika data primer diperoleh dari pihak pertama, berbeda dnegan data sekunder yang dikumpulkan melalui pihak kedua sebagai instansi yang bergerak dibidang pengumpulan data seperti Pemerintah Daerah, Kementerian/Lembaga atau BPS (Arikunto 2013). Matrik antara tujuan, jenis dan sumber data serta output penelitian disajikan dalam Tabel 1.

Tabel 1. Kebutuhan dan sumber data

\begin{tabular}{|c|c|c|c|}
\hline $\begin{array}{l}\mathrm{N} \\
\mathrm{O}\end{array}$ & Tujuan Penelitian & Kebutuhan Data & Sumber Data \\
\hline 1 & $\begin{array}{l}\text { Mengidentifikasi dan } \\
\text { mengkategorisasi } \\
\text { BCB di Kota } \\
\text { Surakarta. }\end{array}$ & $\begin{array}{l}\text { 1. Inventarisasi BCB } \\
\text { 2. Data Blok Bangunan } \\
\text { 3. Penggunaan Lahan Eksisting } \\
\text { 4. Kondisi Bangunan } \\
\text { 5. Kepemilikan/ pengelolaan } \\
\text { 6. Usia BCB } \\
\text { 7. Laggam Arsitektur Bangunan } \\
\text { 8. Potensi Pengembangan } \\
\text { 9. Keterkaitan dengan Sejarah }\end{array}$ & $\begin{array}{l}\text { 1. Citra SPOT } 7 \\
\text { 2. Survey Lapangan } \\
\text { 3. Wawancara } \\
\text { 4. Bappeda Kota Surakarta } \\
\text { 5. Dinas Kebudayaan Kota } \\
\text { Surakarta }\end{array}$ \\
\hline 2 & $\begin{array}{l}\text { Mengukur dan } \\
\text { memetakan tingkat } \\
\text { risiko hilangnya BCB } \\
\text { Kota Surakarta. }\end{array}$ & $\begin{array}{l}\text { 1. Identifikasi dan kategorisasi BCB. } \\
\text { 2. Data dan Peta indikator Bahaya BCB: } \\
\text { a. Perkembangan Perkotaan } \\
\text { - Kepadatan Bangunan } \\
\text { - Kepadatan penduduk } \\
\text { b. Arah Perencanaan Kota } \\
\text { - Rencana pola ruang } \\
\text { c. Bencana Alam }\end{array}$ & $\begin{array}{l}\text { 1. Hasil Ouput Tujuan (1) } \\
\text { 2. Bappeda Kota Surakarta } \\
\text { 3. BPS Kota Surakara } \\
\text { 4. Dinas Pariwisata Kota } \\
\text { Surakarta } \\
\text { 5. Dinas Kebudayaan } \\
\text { Kota Surakarta } \\
\text { 6. Survey Lapangan }\end{array}$ \\
\hline
\end{tabular}




\begin{tabular}{|c|c|c|c|}
\hline $\begin{array}{c}\mathrm{N} \\
\mathrm{O}\end{array}$ & Tujuan Penelitian & Kebutuhan Data & Sumber Data \\
\hline & & $\begin{array}{l}\text { - Peta Rawan bencana } \\
\text { 3. Data dan Peta indikator kerentanan cagar } \\
\text { budaya: } \\
\text { - Kepemilikan/ pengelolaan } \\
\text { - Luas BCB } \\
\text { - Pemanfaatan BCB } \\
\text { - Kondisi BCB } \\
\text { - Usia BCB } \\
\text { - Potensi Pengembangan Ekonomi BCB } \\
\text { - Keterkaitan dengan Sejarah BCB }\end{array}$ & 7. Wawancara Ahli \\
\hline
\end{tabular}

\section{Teknik Analisis Data}

\section{Identifikasi dan Kategorisasi Cagar Budaya}

Identifikasi dan Kategorisasi BCB akan mempermudah dalam menetapkan upaya pelestarian dan konservasi (Mansor et al. 2013). Identifikasi BCB merupakan proses untuk mengenali, memetakan dan mengumpulkan data karakteristik $171 \mathrm{BCB}$, selanjutnya dikategorisasi berdasarkan kesamaan karakteristik melalui teknik pemetaan peta citra resolusi tinggi dengan menggunakan alat ArcGIS 10.2. Tahapan analisis ini adalah (1) Penyiapan data, (2) Digitasi untuk membentuk peta survei, (3) Pelaksanaan survey lapangan, (4) Digitasi on screen hasil identifikasi, (5) Membangun data attribute peta BCB (6) Kategorisasi berdasarkan usia, luas, kondisi bangunan, pemanfaatan, luas, keterkaitan dengan sejarah dan potensi pengembangan ekonomi.

\section{Analisis Tingkat Kerentanan dan Tingkat Bahaya}

Teknik analisis Multi Criteria Decision (MCD) digunakan untuk menentukan tingkat kerentanan dan bahaya $\mathrm{BCB}$ yaitu dengan mempertimbangkan penggunaan beberapa kriteria yang dievaluasi (Riad et al. 2011). Teknik Analisis MCD dilakukan dengan metode Weighted Overlay melalui Sistem Informasi Geografis, dengan tujuan mampu memberikan hasil analisis yang terpadu dengan mempertimbangkan bobot dari masingmasing kriteria yang digunakan. Nilai parameter dan bobot dari masing-masing indikator ditetapkan melalui hasil wawancana expert. Penentuan nilai kriteria dari masing-masing parameter ditetapkan dengan nilai minimal 1 dan maksimal 5 (Buchori et al 2012). Penetapan skala nilai kriteria dari masing-masing parameter yang digunakan sebagai preferensi didasarkan dari modifikasi Chandio (2011) pada Tabel 2.

Tabel 2. Matrik Modifikasi penetapan nilai parameter indikator

\begin{tabular}{cl}
\hline Nilai Kriteria & \multicolumn{1}{c}{ Keterangan } \\
\hline 1 & Sedikit Berkontribusi \\
2 & Cukup berkontibusi \\
3 & Berkontribusi \\
4 & Sangat Berkontribusi \\
5 & Sangat Sangat Berkontribusi \\
\hline
\end{tabular}

Tahapan selanjutnya dalam analisis ini adalah mengkalikan masing-masing nilai masing-masing kriteria dengan bobot dari kriteria sesuai dengan kepentingan. Dalam proses penetapan nilai kriteria dan bobot kepentingan, pengambilan informasi dilakukan dengan memberikan kuestioner kepada beberapa pakar yang dianggap kompeten terkait Eksistensi BCB Kota Surakarta. Sebagai gambaran proses Weighted Overlay dalam penyusunan peta ketentanan dan peta bahaya BCB dapat dilihat dalam Gambar 2. 


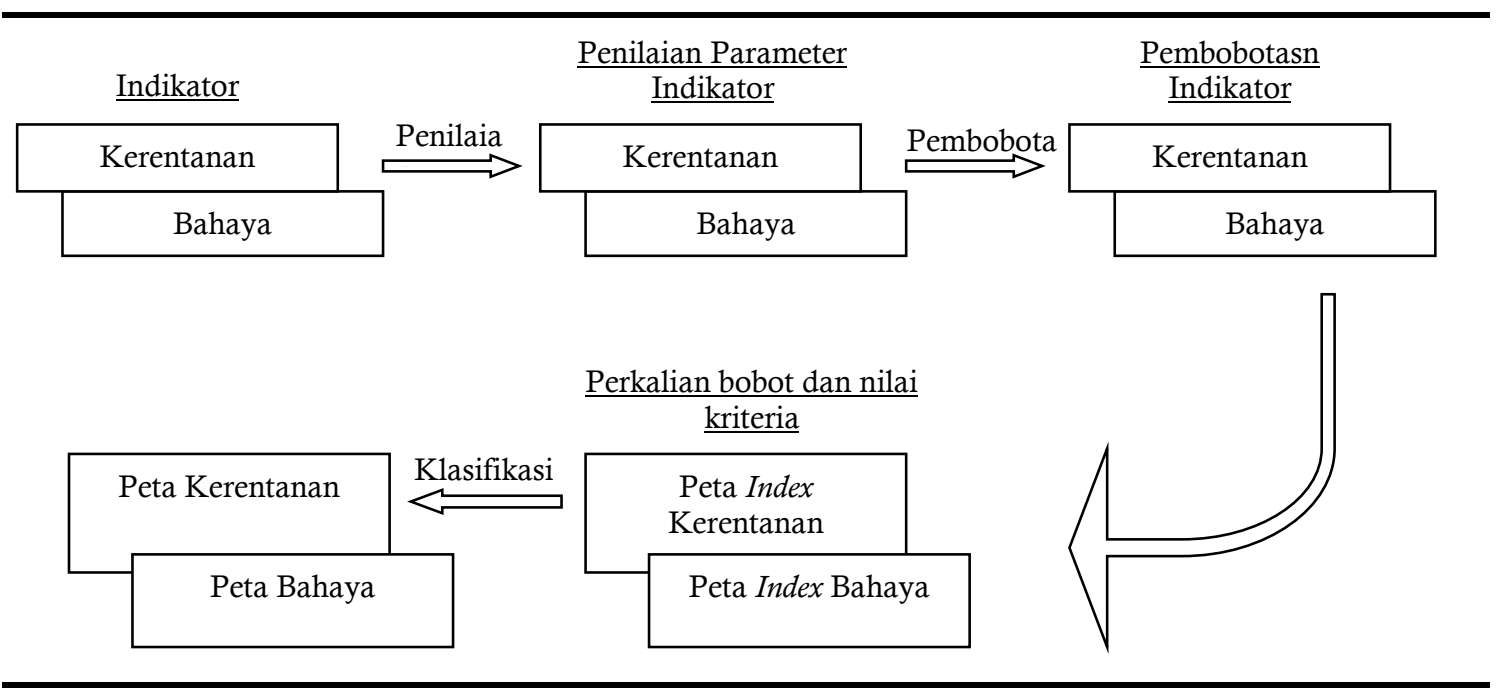

Gambar 2. Proses Weighted Overlay

Kerentanan merupakan keadaan ataupun kondisi dari suatu objek, sistem dan aset yang rentan terhadap keterpaparan bahaya yang merusak (UNISDR 2009). Tingkat kerentanan $\mathrm{BCB}$ didasarkan pada modifikasi indikator kerentanan yang dikemukakan Turner et al. (2003) dan DPCBP (2016) yang disajikan pada Tabel 3.

Tabel 3. Nilai Parameter dan Bobot Indikator Kerentanan

\begin{tabular}{|c|c|c|c|}
\hline Indikator & Parameter Kerentanan & Nilai Parameter & Bobot (\%) \\
\hline \multirow[t]{4}{*}{ Luas } & $<50 \mathrm{~m} 2$ & 5 & 5 \\
\hline & $50-100 \mathrm{~m} 2$ & 4 & \\
\hline & $100-500 \mathrm{~m} 2$ & 3 & \\
\hline & $>500 \mathrm{~m} 2$ & 1 & \\
\hline \multirow[t]{4}{*}{ Pemanfaatan } & Hunian & 4 & 15 \\
\hline & Fasilitas umum/sosial & 3 & \\
\hline & Ekonomi & 5 & \\
\hline & RTH/ Monumen & 1 & \\
\hline \multirow[t]{3}{*}{ Kondisi } & Baik/ Terawat & 1 & 20 \\
\hline & Rusak sebagian & 3 & \\
\hline & Rusak & 5 & \\
\hline \multirow[t]{2}{*}{ Kepemilikan } & Private & 4 & 10 \\
\hline & Publik & 2 & \\
\hline \multirow[t]{3}{*}{ Usia Bangunan } & 50-100 tahun & 2 & 15 \\
\hline & 100-200 tahun & 3 & \\
\hline & $>200$ tahun & 4 & \\
\hline Keterkaitan & Kuat & 1 & 20 \\
\hline \multirow[t]{2}{*}{ Sejarah budaya Kota } & Sedang & 3 & \\
\hline & Lemah & 5 & \\
\hline \multirow{3}{*}{$\begin{array}{l}\text { Potensi pengembangan } \\
\text { sebagai sektor ekonomi }\end{array}$} & Besar & 5 & 15 \\
\hline & Sedang & 3 & \\
\hline & Kecil & 1 & \\
\hline
\end{tabular}

Sementara yang disebut bahaya adalah faktor alami atau fenomena lingkungan yang dapat mengakibatkan kerusakan/ kehilangan atas suatu objek. Dalam kaitannya dengan cagar budaya, faktor-faktor atau fenomena yang menjadi indikator kerusakan/ kehilangan BCB berdasarkan modifikasi ICOMOS (2009) dapat dilihat pada Tabel 4. 
Tabel 4. Nilai Parameter dan Bobot Indikator Bahaya

\begin{tabular}{clcc}
\hline Indikator Bahaya & \multicolumn{1}{c}{ Parameter Bahaya } & Nilai Parameter & Bobot (\%) \\
\hline Kepadatan Penduduk & Sangat Tinggi & 5 & 30 \\
& Tinggi & 4 & \\
& Sedang & 3 & 20 \\
& Rendah & 1 & \\
Kepadatan Bangunan & Tinggi & 5 & 20 \\
& Sedang & 3 & 20 \\
\multirow{5}{*}{ Ranjir } & Rendah & 2 & 30 \\
& Rawan Banjir & 5 & \\
\hline
\end{tabular}

\section{Analisis Risiko Kehilangan Cagar Budaya}

Analisis risiko kehilangan BCB dilakukan dengan melakukan penilaian melalui overlay/operasi tumpang tindih. Analisis overlay dilakukan melalui perangkat lunak Arc GIS 10.2. Dalam Sistem informasi Geografis, analisis overlay dilakukan dengan mempertimbangkan 5 (lima) pilihan fungsi yang tersedia yaitu yaitu (1)Fungsi Logika Boolean, (2) Fungsi aritmatika penambahan, pengurangan, pembagian, dan perkalian, (3) Fungsi relational, (4) Fungsi pemanfaatan atribut tabel, (5) Penyilangan peta langsung (Barus dan Wiradisastra 2009). Peta hasil overlay antara tingkat kerentanan dan bahaya akan dilakukan penilaian untuk menentukan tingkat risiko, berdasarkan tabel hubungan tingkat kerentanan dan bahaya yang dimodifikasi dari penelitian Tarraguel (2011), yang digambarkan pada Tabel 5 .

Tabel 5. Matrik tingkat risiko kehilangan BCB

\begin{tabular}{cccc}
\hline & Bahaya Rendah & Bahaya Sedang & Bahaya Tinggi \\
\hline Kerentanan Rendah & Risiko Rendah & Risiko Rendah & Risiko Rendah \\
Kerentanan Sedang & Risiko Rendah & Risiko Sedang & Risiko Sedang \\
Kerentanan Tinggi & Risiko Rendah & Risiko Tinggi & Risiko Tinggi \\
\hline
\end{tabular}

\section{HASIL DAN PEMBAHASAN}

\section{Kebijakan BCB Kota Surakarta}

BCB merupakan bagian yang tidak terpisahkan dari Kota Surakarta yang dikenal sebagai Kota Budaya yang memiliki banyak peninggalan aset BCB. BCB merupakan hasil peninggalan masa lampau yang perlu dilestarikan keberadaanya. Pemerintah Kota Surakarta memegang peranan yang penting dalam menjaga eksistensi $\mathrm{BCB}$, salah satunya dengan penyusunan kebijakan yang tepat terkait dengan BCB. Salah satu faktor yang dianggap signifikan dalam proses pelestarian cagar budaya adalah dari sisi penataan ruang. Dilihat dari kebijakan penataan ruang Kota Surakarta yaitu Rencana Tata Ruang Wilayah Kota Surakarta Tahun 2011-2031, mengarahkan pengembangan kota dilaksanakan dengan prinsip Eco Cultural City yaitu mengintegrasikan arah pembangunan kota dengan nilai budaya dan lingkungan. Prinsip Eco Cultural City ditanamkan sebagai panduan dalam mewujudkan Kota Surakarta menjadi kota yang tumbuh dengan akar budaya yang kuat dalam pembangunan yang memiliki fokus pada empat komponen utama yaitu ekologi, warisan, ekonomi dan struktur untuk pertumbuhan. Berdasarkan Peraturan Menteri Pekerjaan Umum Nomor 17 Tahun 2009 tentang Pedoman Penyusunan Rencana Tata Ruang Wilayah Kota, disebutkan bahwa cagar budaya dikategorikan sebagai kawasan lindung. Kawasan Lindung sendiri diartikan sebagai kawasan yang memiliki fungsi utama pelestarian mencakup sumber daya alam dan buatan (UU Nomor 26 Tahun 2007). 
Sebagai tindak lanjut dari Rencana Tata Ruang Kota Surakarta dalam upaya integrasi dengan perlindungan terhadap aset cagar budaya, Kota Surakarta menyusun Rencana Aksi Kota Pusaka Tahun 2014 (RAKP) dengan tujuan utama mengintegrasikan kebijakan penataan ruang dengan pengelolaan aset cagar budaya dalam rangka menuju Kota Surakarta sebagai World Heritage Cities (WHC). RAKP mencoba mengintegrasikan antara potensi $\mathrm{BCB}$ sebagai peninggalan masa lampau dengan penataan ruang yang bersifat modern. RAKP mengarahkan program pelestarian dari aspek sosial kelembagaan, aspek administrasi, aspek fisik dan ekonomi yang meliputi (1) manajemen kelembagaan yang terdiri dari pemerintah, swasta, tenaga ahli dan masyarakat, (2) inventarisasi dan dokumentasi kota pusaka, (3) pengembangan potensi ekonomi kota pusaka, (4) pengelolaan manajeman bencana.

BCB merupakan bagian lingkungan kota yang perlu diatur pemanfaatan yang mengedepankan prinsip pelestarian (UU Nomor 11 Tahun 2010). Peraturan Daerah Kota Surakarta tentang Bangunan Gedung secara lebih rinci mengatur pemanfaatan bangunan dengan memperhatikan kaidah pelestarian dengan arahan pemanfaatan untuk kepentingan agama,sosial, pariwisata, pendidikan, ilmu pengetahuan dan kebudayaan. Sebagai upaya pencegahan terhadap perubahan atau pemanfaatan yang tidak sesuai dengan ketentuan yang berlaku, pemerintah Kota Surakarta memberikan batasan dalam proses pemindahtanganan aset $\mathrm{BCB}$.

\section{Identifikasi dan Kategorisasi BCB}

Kota Surakarta merupakan kota dengan sejarah perkembangan yang panjang, dimulai sebagai pusat pemerintahan Mataram yang dibangun di Desa Solo yang dikenal dengan Kraton Surakarta pada tahun 1745. Periode pemerintahan Mataram berakhir setelah adanya perjanjian Giyanti pada tahun 1755 yang mengakibatkan Kerajaan Mataram terpecah menjadi Kraton Kasunanan Surakarta Hadiningrat dan Kraton Kasultanan Ngayogyakarta Hadiningrat.

Perjalanan panjang sejarah kota surakarta, mengakibatkan kota ini dikenal dengan banyak peninggalan $\mathrm{BCB}$ yang bersejarah dan memiliki nilai serta dilindungi oleh masyarakat. Tidak hanya BCB yang merupakan bagian dari sejarah pembentukan kota surakarta, peninggalan masa lampau juga banyak dipengaruhi oleh perkembangan masa kolonial di Kota Surakarta. Peninggalan masa lampau dalam bentuk bangunan merupakan potensi Kota Surakarta, yang dapat diidentifikasi melalui hasil inventarisasi BCB. Proses inventarisasi dilaksanakan secara bertahap dimulai pada tahun 2010 hingga tahun 2014. Hasil inventarisasi BCB Kota Surakarta dapat dilihat pada Tabel 6.

Tabel 6. Inventarisasi BCB Kota Surakarta

\begin{tabular}{|c|c|c|}
\hline No & Penetapan BCB & Jumlah BCB yang ditetapkan \\
\hline 1 & $\begin{array}{l}\text { Surat Keputusan Walikota Surakarta No.646/1- } \\
2 / 1 / 2013 \text { tentang Perubahan Atas keputusan } \\
\text { Walikotamadya Daerah Tingkat II Surakarta } \\
\text { Nomor 646/116/1/1997 tentang Penetapan } \\
\text { Bangunan-Bangunan dan Kawasan Kuno } \\
\text { Bersejarah di Kotamadya Daerah Tingkat II } \\
\text { Surakarta yang dilindungi Undang-Undang } \\
\text { Nomor } 5 \text { Tahun } 1992 \text { tentang Cagar Budaya }\end{array}$ & $\begin{array}{ll} & \text { 4 Komplek Kawasan } \\
\text { - } & 7 \text { Bangunan Rumah Tradisional } \\
\text { - } & \text { 20 Bangunan umum Kolonial } \\
\text { - } & 7 \text { Bangunan Peribadatan } \\
\text { 24 Kelompok gapura, tugu, monumen, } \\
\text { perabot jalan } \\
\text { 8 Ruang Terbuka/ Taman }\end{array}$ \\
\hline 2 & $\begin{array}{l}\text { Keputusan Walikota Surakarta Nomor } 646 / 32- \\
\text { C/1/2013 tentang Penetapan Ndalem } \\
\text { Joyokusuman di Baluwarti, Gedung Eks Rumah } \\
\text { Sakit Jiwa Mangunjayan di Kelurahan } \\
\text { Sriwedari, dan Ponten Mangkunegaran VII di } \\
\text { Kelurahan Kestalan sebagai Cagar Budaya yang } \\
\text { Dilindungi Undang-Undang Nomonr } 11 \text { Tahun } \\
2010 \text { tentang Cagar Budaya }\end{array}$ & $\begin{array}{ll}\text { - } & \text { Ponten Mangkunegaran VII Kestalan } \\
\text { - } & \text { Eks Rumah Sait Jiwa Mangunjayan } \\
\text { - } & \text { Ndalem Joyokusuman }\end{array}$ \\
\hline
\end{tabular}




\begin{tabular}{|c|c|c|}
\hline No & Penetapan BCB & Jumlah BCB yang ditetapkan \\
\hline 3 & $\begin{array}{l}\text { Keputusan Kepala Dinas Tata Ruang Kora } \\
\text { Surakarta Nomor 646/40/I/2014 tentang } \\
\text { Penetapan Bangunan yang Dianggap telah } \\
\text { Memenuhi Kriteria sebagai Cagar Budaya sesuai } \\
\text { Undang-Undang Republik Indonesia Nomor } 11 \\
\text { Tahun } 2010 \text { Tentang Cagar Budaya }\end{array}$ & $\begin{array}{l}100 \text { benda cagarbudaya yang meliputi } \\
\text { bangunan, makam, rumah/ ndalem }\end{array}$ \\
\hline 4 & $\begin{array}{l}\text { Invetarisasi Balai Pelestarian Peninggalan } \\
\text { Purbakala (BP3) Jawa Tengah pada Tahun } 2010\end{array}$ & $\begin{array}{l}\text { - } \quad \text { Terdapat } 91 \text { bangunan yang tercatat dalam } \\
\text { inventarisasi tersebut, namum sebagian } \\
\text { besar telah masuk dalam kategorisasi BCB } \\
\text { yang telah ditetapkan oleh Kota Surakarta. } \\
\text { Terdapat } 17 \text { BCB yang baru yang belum } \\
\text { ditetapkan meliputi bangunan monumen, } \\
\text { rumah tinggal, peribadatan, gapura. }\end{array}$ \\
\hline
\end{tabular}

Dari hasil identifikasi, Kota Surakarta memiliki 171 BCB yang menutupi luas areal sebesar 1.923.648 meter2 atau sebesar 4,37\% dari total luas Kota Surakarta.Keberadaan BCB cenderung memusat di wilayah selatan Kota Surakarta, tepatnya di sekitar Kasunanan Surakarta yang dahulu berfungsi sebagai pusat pemerintahan di Kota Surakarta. Gambaran persebaran BCB di Kota Surakarta dapat dilihat pada Gambar 3.

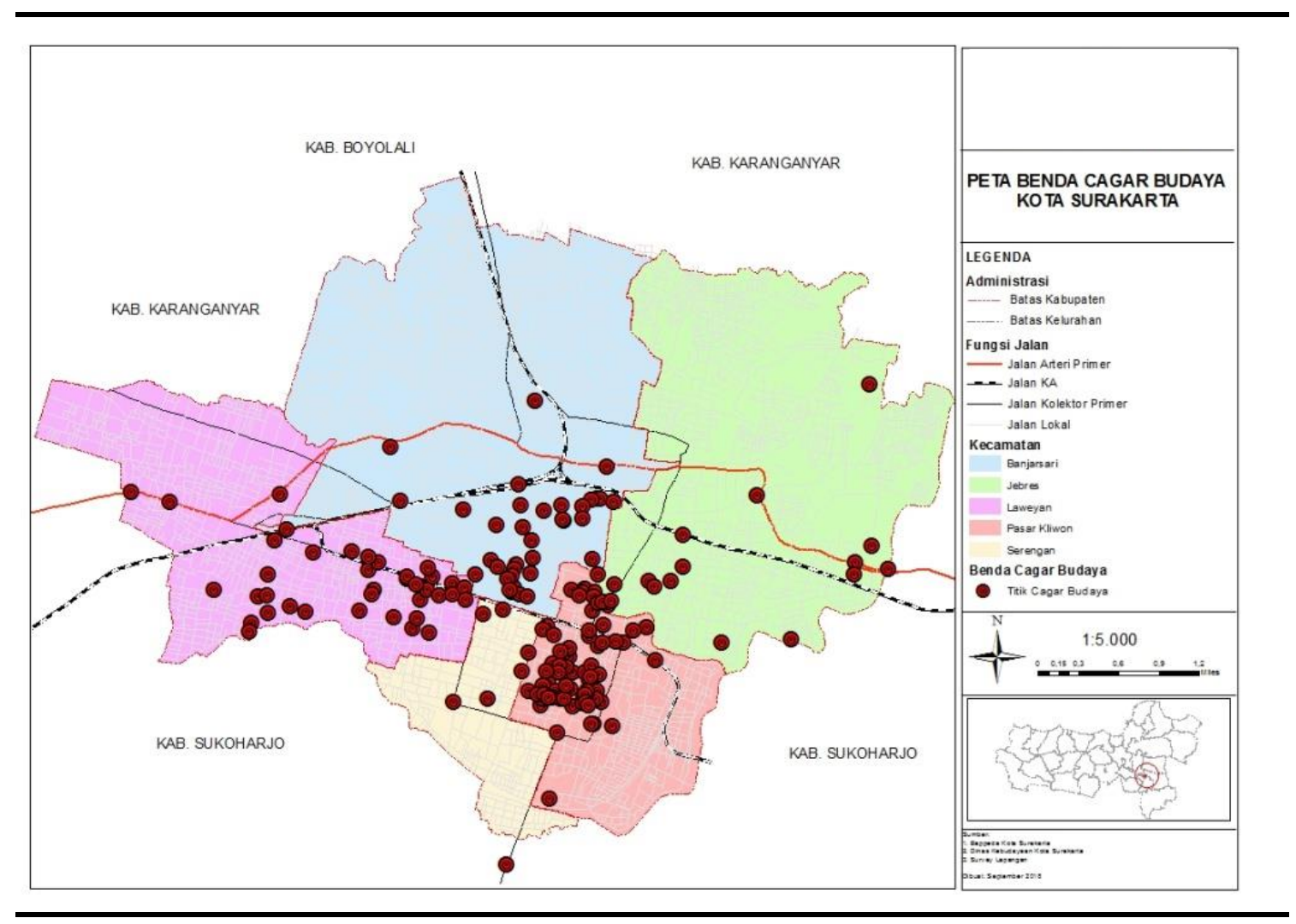

Gambar 3. Persebaran BCB Kota Surakarta

\section{BCB Berdasarkan Usia}

Hasil kategorisadi BCB berdasarkan usia disajikan pada Tabel 7. Dari hasil tersebut diketahui bahwa sebagian besar BCB di Kota Surakarta berada pada rentan usia 100-200. Hal ini menunjukkan bahwa peninggalan BCB dibangun pada masa kolonialisme dan masa pemerintahan Pakubowono X. Hal ini sesuai dengan penelitian yang disampaikan oleh Zaida et al. (2010) yang menyatakan bahwa pada masa tersebut merupakan masa kejayaan ekonomi dan sosial budaya di Kota Surakarta. 
Tabel 7. Jumlah dan luas BCB berdasarkan usia

\begin{tabular}{cccrrr}
\hline No & \multicolumn{1}{c}{ Usia } & $\begin{array}{c}\text { Jumlah } \\
\text { BCB }\end{array}$ & $\begin{array}{c}\text { Persentase Jumlah } \\
(\mathbf{\%})\end{array}$ & Luas (meter ${ }^{2}$ ) & $\begin{array}{c}\text { Persentase } \\
\text { Luas (\%) }\end{array}$ \\
\hline 1 & 50-100 Tahun & 62 & 36,26 & 330.566 & 17,18 \\
2 & 100-200 Tahun & 93 & 54,38 & 887.634 & 46,14 \\
3 & >200 Tahun & 16 & 9,36 & 705.447 & 36,67 \\
\hline
\end{tabular}

BCB yang memiliki usia lebih dari 200 tahun mengelompok pada wilayah bagian selatan Kota Surakarta. Hal ini tidak dapat dipisahkan dari Kasunanan Surakarta sebagai cikal pembangunan kota. Pembangunan kawasan pada masa tersebut membentuk prinsip Mancapat. Mancapat merupakan konsep pembangunan kota kota tradisional di Jawa tengan menempatkan Istana, Alun alun, masjid dan pasar sebagai pusat kota, yang kemudian diikuti oleh permukiman permukiman bagi abdi dalem.

Kategorisasi usia BCB mampu memberikan gambaran tentang arah perkembangan Kota surakarta, dimulai dari sebelah selatan yang terpusat di Jalan Dr. Rajiman, kemudian bergerak ke utara. Dengan demikian, dapat dikatakan BCB mampu menggambarkan sejarah dan perkembangan budaya manusia sebagaimana disampaikan dalam UU Nomor 11 Tahun 2010.

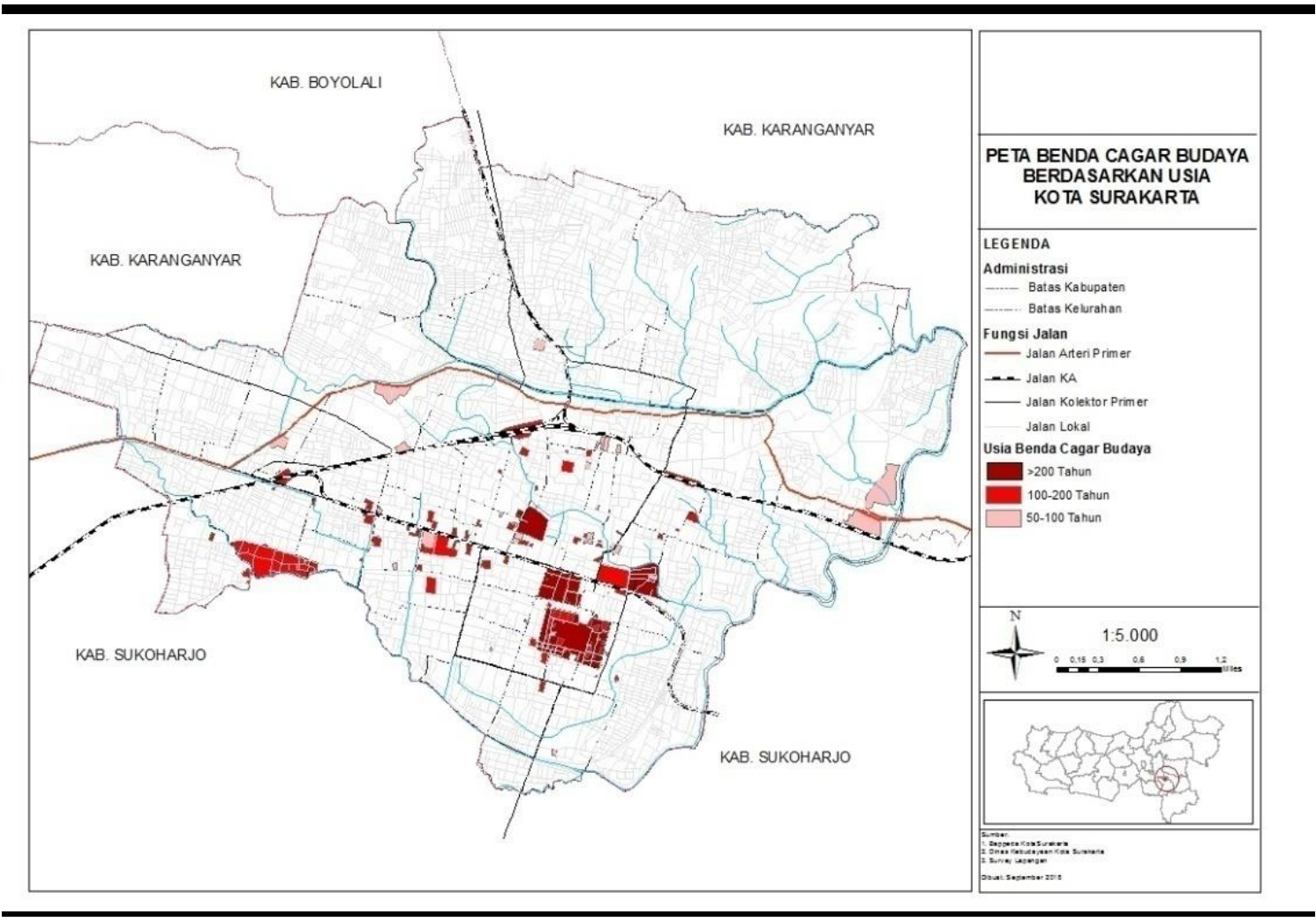

Gambar 4. Peta BCB berdasarkan usia

\section{BCB Berdasarkan Langgam Arsitektur}

BCB melalui langgam arsitektur mencirikan bagaimana kondisi sejarah perkembangan Kota Surakarta dimasa lalu disajikan pada Tabel 5. Sebagian besar BCB yang teridentifikasi memiliki langgam arsitektur tradisional jawa dan kolonial. Hal ini tidak dapat dipisahkan dari sejarah Kota Surakarta sebagai pusat perkembangan budaya Jawa, dan sebagai salah satu wilayah yang menjadi pusat kedudukan Belanda pada masa penjajahan. BCB Kota Surakarta dibangun pada masa yang berbeda mengakibatkan munculnya keragaman dalam 
langgam arsitekturnya, hal ini sesuai dengan kriteria penetapan cagar budaya berdasarkan UU Nomor 11 Tahun 2010 yang menyebutkan bahwa BCB di Surakarta mampu mewakili masa gaya tertentu.

Tabel 8. Jumlah dan Luas BCB Berdasarkan Langgam Arsitektur

\begin{tabular}{llrrrr}
\hline No & Langgam Arsitektur & Jumlah & $\begin{array}{c}\text { Persentase } \\
\text { Jumlah (\%) }\end{array}$ & Luas (meter ${ }^{2}$ ) & $\begin{array}{c}\text { Persentase Luas } \\
\text { (\%) }\end{array}$ \\
\hline 1 & Tadisional Jawa & 78 & 45,03 & 1.264 .196 & 65,72 \\
2 & Kolonial Jawa & 13 & 7,60 & 44.047 & 2,29 \\
3 & Kolonial & 64 & 37,43 & 416.984 & 21,68 \\
4 & Islam & 2 & 1,17 & 3.813 & 0,20 \\
5 & Tionghoa & 3 & 1,75 & 737 & 0,04 \\
6 & Semi Modern & 12 & 7,02 & 193.870 & 10,08 \\
\hline
\end{tabular}

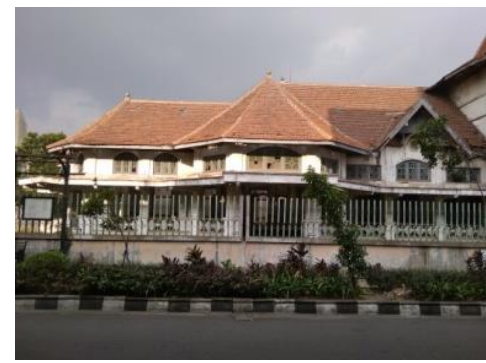

(i) Kolonial

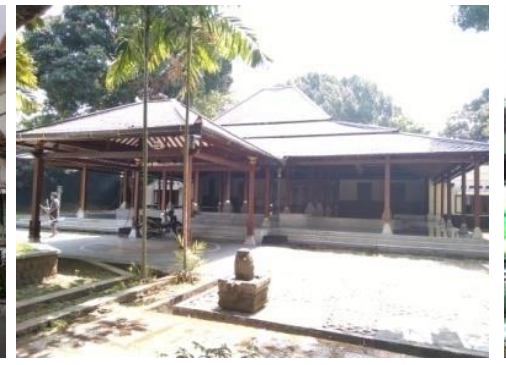

(ii) Tradisional Jawa

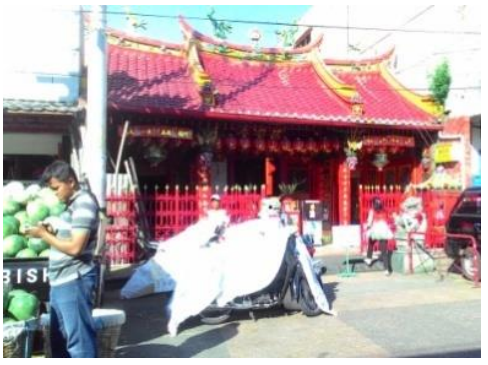

(iii) Tionghoa

Gambar 5. BCB berdasarkan langgam arsitekturnya

Langgam arsitektur yang beragam pada BCB mampu memberikan gambaran visual yang khas bagaimana perkembangan budaya dan penguasaan Kota Surakarta di masa lampau. Hal ini sejalan dengan yang dikemukakan oleh Almadani et al. (2013), bahwa gambaran arsitektural merupakan cerminan dari perubahan waktu, budaya dan tata cara yang berkembang dalam kehidupan masyarakat di suatu wilayah.

\section{BCB Berdasarkan Kondisi}

Hasil kategorisasi berdasarkan kondisi BCB disajikan pada Tabel 9, dimana dapat dilihat bahwa tidaksemua $\mathrm{BCB}$ dalam kondisi yang baik dan terawat. Terdapat $\mathrm{BCB}$ yang rusak total sebanyak 9 unit. Kerusakan $\mathrm{BCB}$ yang diikuti dengan kerusakan struktur arsitektur bangunan dapat dikatakan sebagai permasalahan yang serius, karena kerusakan BCB merupakan proses rusaknya orientasi sejarah (Mansor et al. 2010). Terlebih lagi sifat $\mathrm{BCB}$ adalah tidak dapat diperbaharui. Tantangan bagi eksistensi BCB salah satunya adalah pembangunan yang mengarah pada moderinasi (Perles et al. 2018). Hal tersebut juga ditemui pada $\mathrm{BCB}$ di Kota surakarta, dimana 5 BCB dengan luas 4.446 meter2 $(0,23 \%)$ mengalami perubahan langgam arsitekturnya menjadi bangunan modern dan meninggalkan nilai arsitektural aslinya.

Tabel 9. Jumlah dan Luas BCB Berdasarkan Kondisi

\begin{tabular}{llcrrr}
\hline No & Usia Kondisi Bangunan & Jumlah & $\begin{array}{r}\text { Persentase Jumlah } \\
\text { (\%) }\end{array}$ & Luas (meter ${ }^{2}$ ) & $\begin{array}{c}\text { Persentase Luas } \\
\text { (\%) }\end{array}$ \\
\hline 1 & Baik & 122 & 71,35 & 901.344 & $46,86 \%$ \\
2 & Rusak sebagian & 35 & 20,47 & 970.768 & $50,46 \%$ \\
3 & Rusak & 9 & 5,26 & 47.090 & $2,45 \%$ \\
4 & Moderinasi & 5 & 2,92 & 4.446 & $0,23 \%$ \\
\hline
\end{tabular}



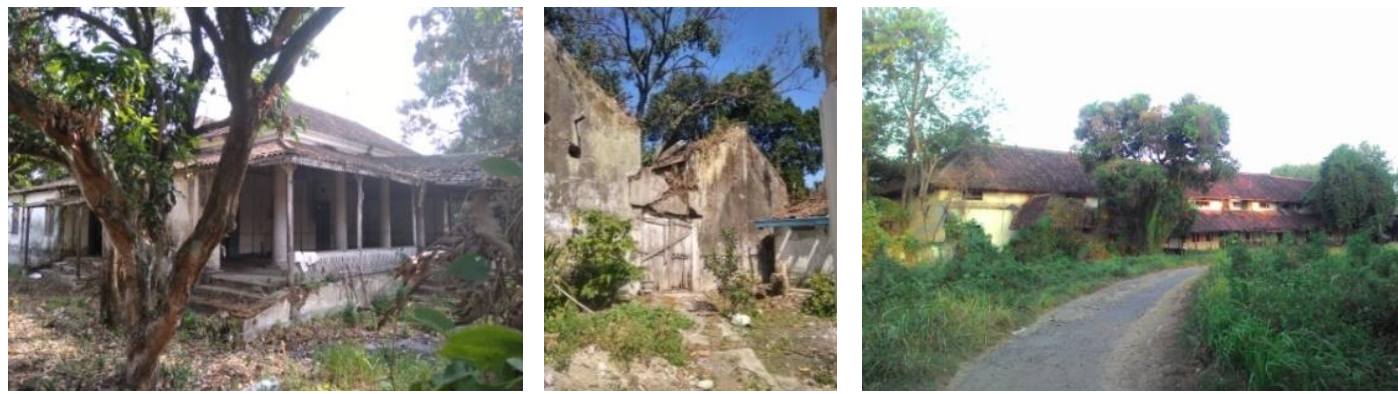

Gambar 6. Bentuk kerusakan BCB Kota Surakarta

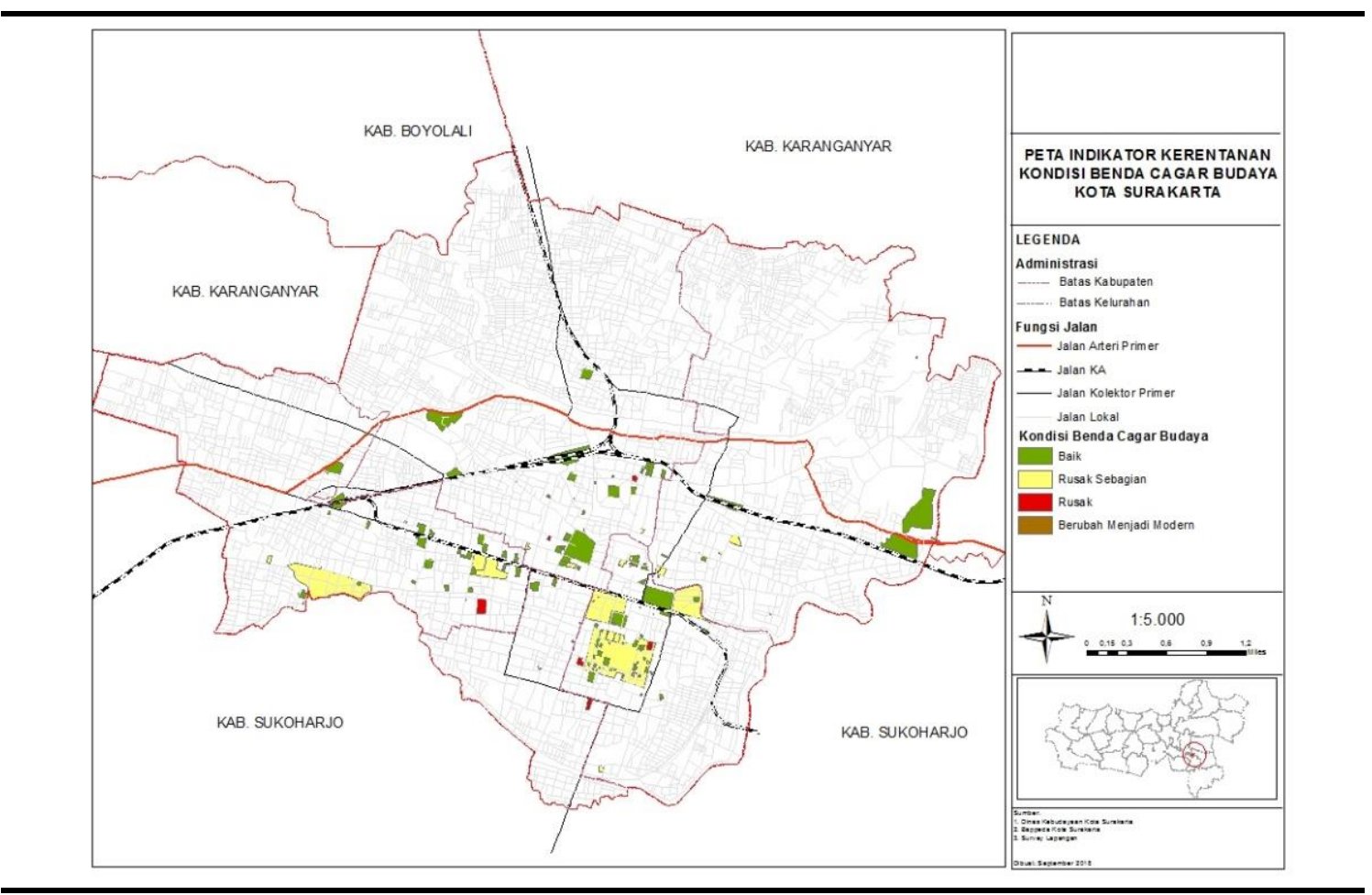

Gambar 7. BCB berdasarkan Kondisi

\section{BCB Berdasarkan Kepemilikan}

Hasil kategorisasi BCB berdasarkan kepemilikan menunjukkan bahwa 95 BCB yang menutupi wilayah sebesar 1.160 .855 meter2 merupakan miliki pribadi/perseorangan. Sementara sisanya sebesar71 BCB dengan total luas 762.793meter2 merupakan miliki Pemerintah Pusat/ Pemerintah Daerah. Dalam RAKP (2014), diketahui bahwa kepemilikan $\mathrm{BCB}$ oleh perseorangan merupakan tantangan besar dalam proses pelestarian, berkaitan dengan sistem waris yang menjadi bagian dari budaya di Indonesia.Hal ini dikarenakan kepemilikan sebagai hak terkuat dalam proses pengelolaan BCB sebagaimana disampaikan dalam Peraturan Daerah Kota Surkarta Nomor 10 Tahun 2013 tentang Pelestarian Cagar Budaya.

Faktor kepemilikan merupakan hal yang sangat berperan dalam proses pelestarian $\mathrm{BCB}$ sehingga segala bentuk pengelolaan $\mathrm{BCB}$ baik yang bersifat private atau publik. Hal tersebut salah satunya dengan pengaturan mengenai hak terhadap pemilik BCB dalam hal pemindah tanganan atau jual beli, dimana harus dilakukan setelah adanya izin dari 
pemerintah daerah. Selain itu, segala bentuk upaya perubahan pemanfaatan terhadap BCB dilakukans sesuai dengan klasifikasi yang diatur dalam Peraturan Daerah Nomor 8 Tahun 2016.

\section{Tingkat Kerentanan BCB}

Tingkat Kerentanan disusun berdasarkan indikator Kerentanan yang disajikan pada Tabel 3. Indikator Kerentanan menggambarkan Karakteristik BCB yang unik, langka, dan nonrenewable menciptakan terjadinya kondisi yang rentan terhadap kerusakan maupun kehilangan. Hasil analisis kerentanan weigted disajikan pada Tabel 10.

Tabel 10. Tingkat Kerentanan BCB Kota surakarta

\begin{tabular}{|c|c|c|c|c|c|}
\hline No & Tingkat Kerentanan & Jumlah BCB & $\begin{array}{l}\text { Persentase } \\
\text { Jumlah (\%) }\end{array}$ & Luas (meter ${ }^{2}$ ) & $\begin{array}{c}\text { Persentase } \\
\text { Luas (\%) }\end{array}$ \\
\hline 1 & Rendah & 52 & 30,41 & 289.981 & 15,07 \\
\hline 2 & Sedang & 82 & 47,95 & 647.158 & 33,64 \\
\hline 3 & Tinggi & 37 & 21,64 & 986.509 & 51,28 \\
\hline
\end{tabular}

Dari hasil analisis pada Tabel 7, disebutkan bahwa terdapat 21,64\% BCB yang melingkupi luas $986.509 \mathrm{~m} 2$ berada pada tingkat kerentanan yang tinggi, sehingga dapat dikatakan bahwa BCB tersebut semakin sulit mempertahankan eksistensinya jika dihadapkan dengan keterpaparan bahaya (Tarraguel 2011). Gambar 4 menunjukkan bahwa $\mathrm{BCB}$ dengan tingkat kerentanan tinggi merupakan $\mathrm{BCB}$ memusat di wilayah selatan Kota Surakarta. Wilayah ini merupakan pusat pertumbuhan yang dalam RTRW Kota Surakarta ditetapkan sebagai pusat pemerintahan, ekonomi, dan pariwisata. Hal ini sejalan dengan pendapat DPCBP (2013), yang menyatakan bahwa peningkatan kerentanan BCB berbanding lurus dengan desakan pembangunan wilayah.

Tingkat kerentanan tinggi tersebut ditemui pada BCB yang menjadi cikal bakal pembangunan kota surakarta dengan usia lebih dari 200 tahun. Hal ini menunjukkan bahwa, secara fisik bangunan yang memiliki usia lebih tua akan memiliki kerentanan yang tinggi terhadap kerusakan, akibat struktur bangunan yang mudah lapuk, dan rapuh (Almadani et al. 2013).

\section{Tingkat Bahaya BCB}

Tingkat bahaya dianalisis berdasarkan indikator bahaya yang disajikan pada Tabel 2. Dari hasil analisis yang disampaikan pada Tabel 8 , diketahui bahwa sebagian besar BCB berada pada tingkat keterpaparan bahaya sedang. Sementara BCB dengan tingkat bahaya yang tinggi sebesar $43 \mathrm{BCB}$ yang meliputi luas $608.937 \mathrm{~m} 2$. Tingkat bahaya yang tinggi terpusat di wilayah tengah sampai dengan timur Kota Surakarta (Gambar 9). Pada wilayah ini merupakan pusat aktivitas di Kota Surakarta, dengan tingkat kepadatan bangunan dan penduduk yang tinggi. Hal ini menunjukkan bahwa tekanan pembangunan yang ditunjukkan dengan peningkatan jumlah bangunan dan penduduk menjadi faktor yang mempengaruhi $\mathrm{BCB}$ sulit untuk dapat mempertahankan eksistensinya.

Tabel 11. Tingkat Bahaya BCB Kota Surakarta

\begin{tabular}{|c|c|c|c|c|c|}
\hline No & Tingkat Bahaya & Jumlah & $\begin{array}{c}\text { Persentase Jumlah } \\
(\%)\end{array}$ & Luas (meter $\left.{ }^{2}\right)$ & $\begin{array}{c}\text { Persentase Luas } \\
(\%)\end{array}$ \\
\hline 1 & Rendah & 33 & 19,30 & 439.460 & 22,85 \\
\hline 2 & Sedang & 97 & 56,73 & 875.251 & 45,50 \\
\hline 3 & Tinggi & 43 & 25,15 & 608.937 & 31,66 \\
\hline
\end{tabular}




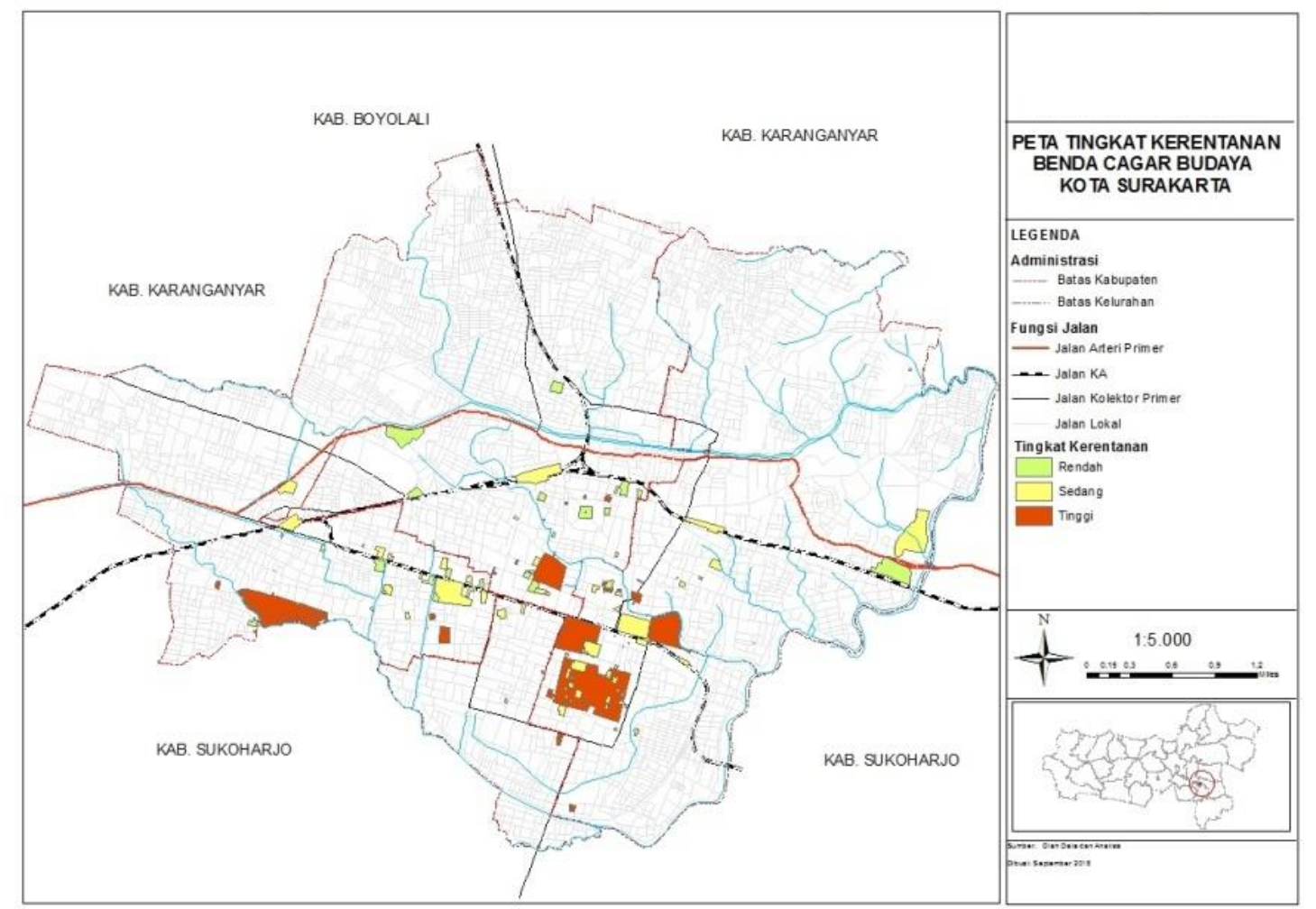

Gambar 8. Peta Tingkat Kerentanan BCB Kota surakarta

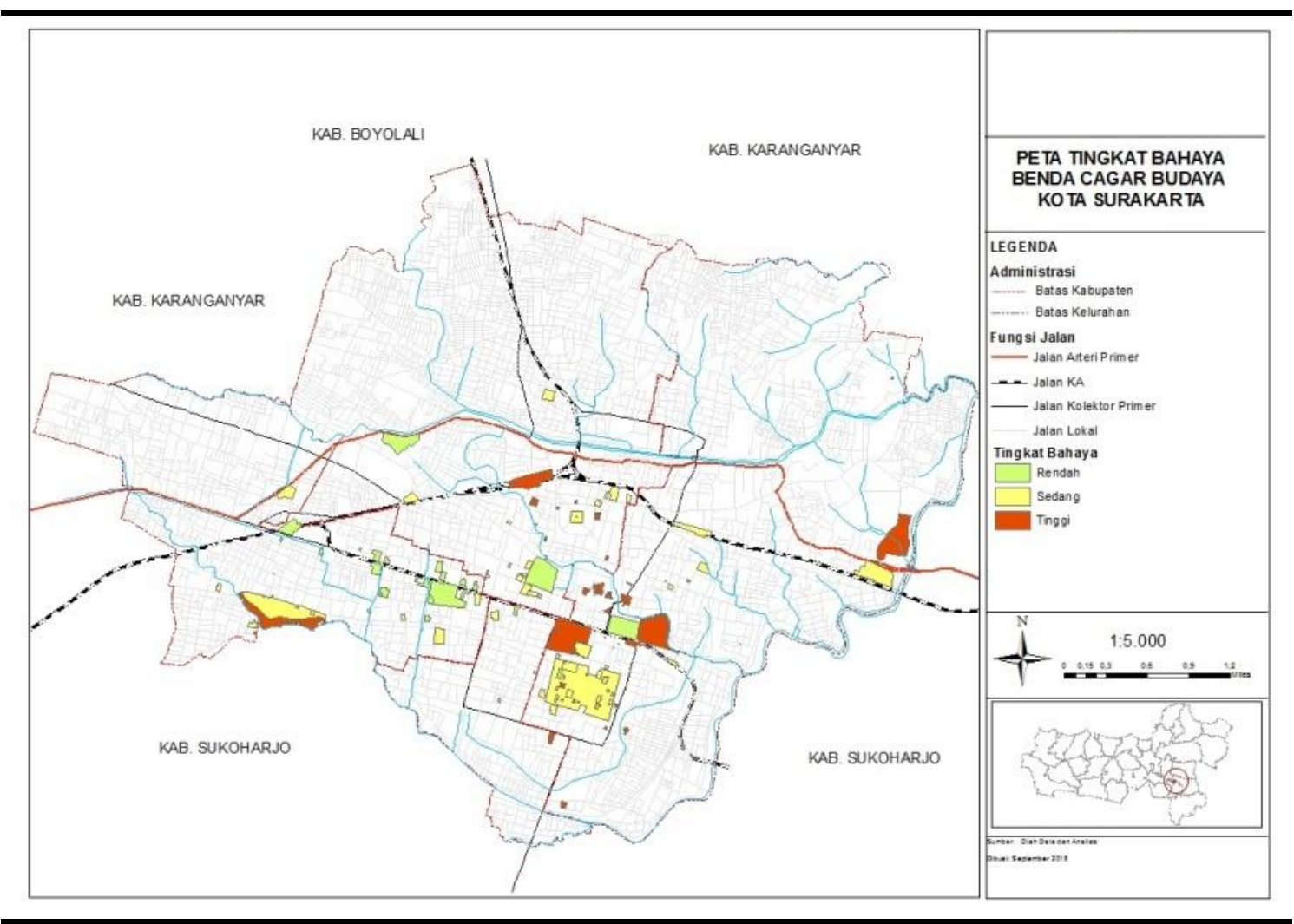

Gambar 9. Peta tingkat bahaya BCB Kota Surakarta 
Jika melihat pada gambar 9, diketahui bahwa kawasan permukiman Baluwarti dan Kasunanan Surakarta, merupakan kawasan dengan tingkat kepadatan penduduk dan bangunan tinggi, serta sebagian wilayah merupakan rawan banjir akan tetapi menunjukkan tingkat bahaya yang sedang. Hal ini dipengaruhi oleh kedudukan kawasan tersebut sebagai kawasan lindung cagar budaya. Kondisi tersebut menjadi sebuah pembenaran atas pernyataan ICOMOS (2015), bahwa penataan ruang memegang peranan penting dalam menciptakan bahaya terhadap BCB.

\section{Tingkat Risiko BCB}

Dari hasil analisis risiko $\mathrm{BCB}$, sebagaimana disampaikan pada Tabel 9, diketahui bahwa terdapat 33 unit BCB yang memiliki risiko kehilangan eksistensi tinggi. BCB yang memiliki tingkat risiko tinggi memusat di wilayah sebelah selatan Kota Surakarta (Gambar 6). Wilayah selatan Kota Surakarta merupakan pusat pertumbuhan ekonomi dan pembangunan di Kota surakarta sejak jaman dahulu, sehingga hal ini menunjukkan bahwa semakin tinggi tekanan pembangunan akan meningkatkan risiko $\mathrm{BCB}$. Hal ini sejalan dengan kajian dalam ICOMOS (2015), yang menyatakan bahwa BCB yang berada ditengah pembangunan, mengarah pada meningkatnya risiko kehilangan/ kerusakan.

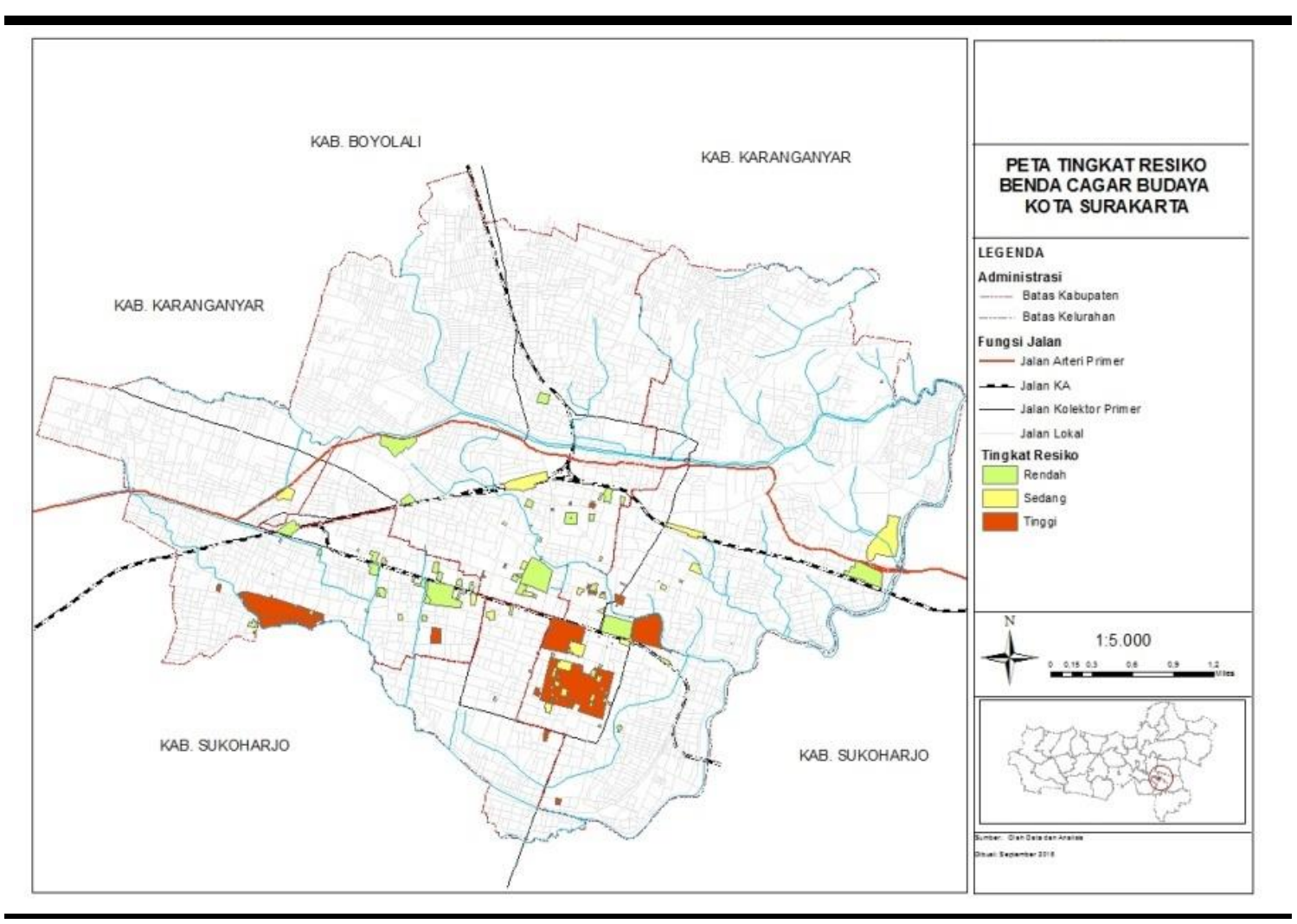

Gambar 10. Peta Tingkat Risiko BCB Kota Surakarta

Tabel 12. Tingkat Risiko BCB Kota Surakarta

\begin{tabular}{cccccc}
\hline No & Risiko & Jumlah & Persentase Jumlah (\%) & Luas ( $\mathbf{m}^{\mathbf{2}}$ ) & Persentase Luas (\%) \\
\hline 1 & Rendah & 73 & $42,69 \%$ & 640.449 & $33,29 \%$ \\
2 & Sedang & 64 & $37,43 \%$ & 396.642 & $20,62 \%$ \\
3 & Tinggi & 33 & $19,30 \%$ & 886.556 & $46,09 \%$ \\
\hline
\end{tabular}


Tabel 13. Tingkat Risiko BCB dilihat dari rencana pola ruang

\begin{tabular}{llcr}
\hline \multicolumn{1}{c}{ Tingkat Risiko } & Rencana Pola Ruang & Jumlah & Luas (meter ${ }^{2}$ ) \\
\hline Risiko Tinggi & Lindung & 12 & 77.570 \\
& Budidaya & 21 & 543.466 \\
Risiko Sedang & Lindung & 23 & 343.085 \\
& Budidaya & 39 & 319.080 \\
Risiko Rendah & Lindung & 18 & 321.828 \\
& Budidaya & 59 & 318.618 \\
\hline
\end{tabular}

Penentuan tingkat risiko merupakan bagian dari mitigasi dalam proses pelestarian $\mathrm{BCB}$. $\mathrm{BCB}$ yang memiliki tingkat risiko tinggi maka semakin tinggi potensi untuk kehilangan eksistensinya, sehingga perlu dilakukan perlindungan. Tabel 10 menunjukkan bahwa 21 $\mathrm{BCB}$ dengan tingkat risiko tinggi ditetapkan sebagai kawasan budidaya. Hal ini menunjukkan bahwa $\mathrm{BCB}$ dengan risiko tinggi, dilihat dari arahan penataan ruang tidak ditetapkan sebagai kawasan dengan fungsi perlindungan. Hal ini bertentangan dengan pernyataan ICOMOS (2015) yang menyampaikan bahwa perencanaan tata ruang memiliki kedudukan yang penting dalam upaya perlindungan BCB.

\section{KESIMPULAN}

BCB merupakan potensi pembangunan di Kota Surakarta. Kota Surakarta diidentifikasi memiliki $171 \mathrm{BCB}$ yang tersebar di seluruh wilayah Kota Surakarta. Sebagian besar BCB memiliki usia 100-200 tahun dengan dominasi langgam arsitektur tradisional jawa dan kolonial. BCB tidak sepenuhnya berada dalam kondisi baik, sebanyak 20,47\% mengalami kerusakan sebagian, 5,26\% mengalami kerusakan total dan 2,92\% telah mengalami modernisasi. Tingkat risiko BCB ditentukan berdasarkan kerentanan dan bahaya, diketahui bahwa 42,69\% unit berada pada tingkat risiko rendah, 37,43\% memiliki risiko sedang dan $19,30 \%$ unit memiliki risiko tinggi kehilangan eksistensi. BCB yang memiliki risiko tinggi berada pada wilayah selatan kota, yang memiliki tingkat perkembangan wilayah cukup tinggi.

\section{DAFTAR PUSTAKA}

Almadani, MR, Gunawan, I. 2013. Identifikasi Bangunan Cagar Budaya Bangunan Kuning Agung, Senghie, Pontianak. Lanting Journal of Architecture 2 (1):17-28.

Arikunto, S. 2013. Prosedur Penelitian Suatu Pendekatan Praktik. Jakarta (ID): Rineka Cipta.

Barus, B dan Wiradisastra, US. 2009. Sistem Informasi Geografis: Sarana Manajemen sumberdaya. Bogor (ID): IPB.

Buchori, I, Susilo, J. 2012. Model Keruangan untuk Identifikasi Kawasan Longsor. TATALOKA 4 (4): $282-294$.

Chandio, IA, Nasir, A. 2011. GIS-based Multi-criteria Decision Analysis of Land Suitability for Hillside Development. International Journal of Environmental Science and Development 2 (6): 469-473.

[DTRK] Dinas Tata Ruang Kota Surakarta. 2014. Rencana Aksi Kota Pusaka Tahun 2014. Surakarta (ID): Dinas Tata Ruang Kota Surakarta.

Direktorat Pelestarian Cagar Budaya dan Permuseuman. 2016. "Pemahaman Tentang Vulnerability pada Cagar Budaya" diakses dari https://kebudayaan.kemdikbud.go.id/ditpcbm, pada tanggal 1 April 2018.

Eastman, JR. 2006. IDRISI Andes Guide to GIS and Image Processing. Worcester (US): Clark University.

[ICOMOS]. International Council on Monuments and Sites. 2009. World Heritage in Danger. Paris (FR): International Council on Monuments and Sites.

[ICOMOS] International Council on Monuments and Sites. 2015. Culture Heritage, the UN Sustainable Developments Goals, and the New Urban Agenda. Paris (FR): International Council on Monuments and Sites.

Mansor, M, Latip, Mohamod, LH. 2013. Identifying Cultural Landscape Components in the District of Kuala Kangsar, Perak, Malaysia. Asian Cultural Landscape Association International Symposium; 12-14 Oktober 2013; Seoul (KR); ACLA:65-72.

Perles, A and Garcia-Diego, F. 2018. An energy-efficient internet of things (IoT) architecture for preventive conservation of cultural heritage. Future Generation Computer Systems. 81: 566-581. 
Riad, PHS, Bilib, M, and El Din, ME. 2011. Application of The Overlay Weighter Model and Boolean to Determine the Best Locations for Artificial Recharge of Grounwater. Journal Urban and Enviromental Enginering. 5 (2): 57-66.

Runa, IW, Warnata, IN dan Mahaputra, ING. 2011. Heritage Area Conditions in The City Centre of Denpasar. Denpasar (ID): Universitas Warmadewa.

Shafaghat, A, Ghaserni, MM, and Ferwati, MS. 2017. Sustainable riverscape preservation strategy framework using goaloriented method: Case of historical heritage cities in Malaysia. International Journal of Sustainable Built Environment (6): 143-159.

[Setneg] Sekretariat Negara Republik Indonesia. 2007. Undang-Undang Nomor 26 Tahun 2007 tentang Penataan Ruang. Jakarta (ID): Sekretariat Negara.

[Setneg] Sekretariat Negara Republik Indonesia. 2010. Undang-Undang Nomor 11 Tahun 2010 tentang Cagar Budaya. Jakarta (ID): Sekretariat Negara.

Sugiyono. 2010. Metode Penelitian Pendidikan Pendekatan Kuantitatif, kualitatif,dan R\&D. Bandung (ID): Alfabeta.

Tarraguel, AA. 2011. Developing an Approach for Analysing the Possible Impact of Natural Hazards on Cultural Heritage: a Case Study in the Upper Svaneti region of Georgia [Tesis]. Enschede (NL): University of Twente.

Turner, BJ, Kasperson, Christensen, L, Luers, A, Polsky, C, Pulsipher, A, [UNISDR] United Nations Officer of Disaster Risk Reduction. 2009. Terminology on Disaster Risk Reduction. Geneva (ZH): UNISDR.

[UNISDR] United Nations Officer of Disaster Risk Reduction. 2009. Terminology on Disaster Risk Reduction. Geneva (ZH): UNISDR.

Wibowo, AB. 2012. Strategi Pelestarian Benda/Situs Cagar Budaya Berbasis Masyarakat Kasus Pelestarian Benda/Situs Cagar Budaya Gampong Pande Kecamatan Kutaraja Banda Aceh Provinsi Aceh. Banda Aceh (ID): Badan Pelestarian Nilai Budaya Banda Aceh.

Zaida, SNA, dan Arifin, NHS. 2010. Surakarta: Perkembangan Kota sebagai Akibat Pengaruh Perubahan Sosial Pada Bekas Ibukota Kerajaan di Jawa. Jurnal Lanskap Indonesia. 2 (2): 83-92. 